\title{
Segregation From a Normative Perspective
}

\author{
Adam Swift (University College London)
}

\begin{abstract}
:
I present a general framework for thinking about why educational segregation might matter from a normative perspective. The framework is presented through discussion of policies that permit schools to select their students.
\end{abstract}

Keywords:

admissions policy; children's rights; educational goods; parents' rights; segregation

Once we see that segregation is a matter of degree, rather than all-or-nothing, we see it everywhere. There is segregation by class, by status, by racialized group, by gender, by religion, by age... There is residential segregation, workplace segregation, educational segregation, segregation between places of religious worship, segregation between public toilets, segregation when it comes to who people live with or have children with...

We can study all these kinds of segregation as social scientists, in descriptive and explanatory mode. Descriptively, we can ask about their extent, about how much they overlap, about trends over time, about differences between societies. From an explanatory perspective, we can interrogate their causes and effects. Why are residential neighbourhoods racially segregated? How does the patterning of who works where result from, and influence, gender norms? To what extent does people's tendency to have children with others of similar levels of education - educational homogamy - help to explain social (im)mobility ?

But we can also investigate these empirical phenomena from a normative perspective, thinking carefully about whether these various kinds of segregation matter. Is a particular instance of segregation good or bad, just or unjust? Should we be trying to do something about it, and if so what? Both causes and effects are relevant here. For example, it obviously makes a big difference, normatively speaking, whether people are voluntarily choosing to live in neighbourhoods alongside, or have children with, their co-religionists, or members of the same racialised group, or whether they are forced to do so by state policy. But even where segregation does result from individuals' apparently "free" choices, we can still interrogate the circumstances that lead them to choose as they do, and of course it will still be important how those choices, however freely made, affect others.
Social scientists' descriptive and explanatory agendas are typically motivated by normative concerns. They study segregation because they think it matters in some way, but their views about why it matters tend to be somewhat vague or diffuse. That is hardly surprising, they are trained in other skills, but it is regrettable. We need a clear sense of the different normative considerations at stake - the values and rights - if we are to make the fine-grained judgments required to come up with the right policies.

My aim in this short piece is to offer a general normative framework for thinking about segregation, and the policies that help to produce it, in the case of schools. Schools can be segregated along various different dimensions such as class, measured ability, race, gender, and religion. Selective admissions policies are the most obvious way in which the rules regulating schools influence segregation between them, so I will focus on them. ${ }^{1}$

\section{Composition Effects and Segregation by Selection}

Selective admissions policies segregate children and influence the composition of schools. They do this both for schools that are selecting students and those that are not. Of course, admission policies are not the only factors in play. A school could be composed entirely of children of co-religionists without being permitted to use religious selection criteria. It could be allowed to select on that basis yet be substantially composed of pupils from another religious background altogether. Still, admissions policies are an important part of the story.

Why does it matter how pupils with different characteristics are grouped together in schools? The answer, at its most general, is "composition effects". These are all the ways that the composition of a school makes a difference to those who attend it. Even if it had no impact on their test or exam results, schools composed entirely of boys, or of children who had passed an entrance exam, or 
whose parents were practising Catholics, might be expected to produce students with different characteristics from those they would have had if they had gone to coeducational schools, comprehensive schools, or schools composed of children from many religious backgrounds.

School composition can affect a wide range of outcomes, and it can produce those outcomes through a wide variety of different mechanisms. The mechanisms will differ depending on the particular dimension of composition (e.g., gender, measured ability, religious background) and the particular outcomes (e.g., academic results, capacity for healthy personal relationships, understanding of those with a different religious outlook) in question. In order to be a composition effect, it must be that some properties of the pupils in question combine to produce the effect.

\section{Two Kinds of Normative Consideration}

Arguments for and against selective admissions policies - and the various forms of segregation to which they contribute - invoke two kinds of consideration:

1) Consequentialist: selection produces (or fails to produce) various kinds of good or benefit, and/or it distributes those goods or benefits well (or badly).

2) Non-consequentialist: whether or not it produces (or fails to produce) benefits, selection respects (or fails to respect) people's rights.

Let us consider each of these in turn.

\section{Consequentialist}

Arguments that segregation makes schools better tend to operate with an implicit view about what it means for schools to be better and worse. Often the claim concerns exam results or test scores. These are indicators of a good thing that we want schools to produce - call it cognitive capacity - which in turn might be valued partly because of its importance for children's labour market prospects. But schools should aim at other goals too. Perhaps it is important for children to develop "soft skills". Perhaps it is also valuable that schools produce children with certain democratic competences or liberal attitudes (e.g., tolerance). And so on.

This point has been systematized in the concept of "educational goods" (Brighouse et al., 2018). These are the knowledge, skills, dispositions and attitudes that help people's lives go better as adults and contribute to the quality of other people's lives. Brighouse et al. identify six capacities - for economic productivity, personal autonomy, democratic competence, healthy personal relationships, treating others as equals, and personal fulfilment - that we should want schools to develop in children. One might dispute the details, but it is hard to deny that claims about what makes schools "better" (or "worse") should attend both to the specific way(s) they are better and to the possibility of trade-offs between different educational goods.

It matters also how those goods, and access to those goods, are distributed. Parents are often concerned only with whether benefits accrue to their own children, but policymakers must think about how segregation is likely to impact on both the overall distribution of those benefits and the distribution of opportunities to achieve those benefits. A school might be good at producing high test scores and good citizens, but it might do so in ways that make it very hard for other schools to do either, or that achieve those outcomes only by an unfair distribution of opportunities to access the better outcomes. Familiar debates in the literature on educational justice - about educational equality, adequacy and the idea of prioritizing benefits to the least or less advantaged - play out, in various ways, in arguments about segregation, usually with a focus on selection by parents' ability to pay or by students' measured ability (Clayton, 2018).

Careful thinking about consequences requires attending to two further points: (i) educational goods can produce benefits for people other than the educated person, and (ii) those benefits need not themselves be understood as consisting of educational goods. Consider, for example, the benefits achieved by educating children to be democratically competent, or to relate to one another as equals. Here the good consequences that follow from educating children so that they possess the capacities in question accrue at least partly to those with whom the children do, or will, interact. The educational goods produce positive externalities or "spill overs". And here those benefits are not themselves "educational goods", or at least not exclusively so. They are those that come from living in a polity where one's fellow citizens are democratically competent, or in which they regard one another as equals.

To evaluate segregation in schools from a consequentialist perspective one must keep in mind both the full range of benefits produced by educational goods and the fact that those benefits need not accrue entirely to the people who possess the educational goods themselves. Suppose, for example, that segregation increased some children's level of some or all educational goods but decreased the level of some or all educational goods received by other children. We cannot assess the full distributive impact without knowing the effect on all relevant measures of advantage. Perhaps, for example, an increase in cognitive skills enjoyed by some will result in scientific advances that benefit, in other ways, precisely those who suffer the loss with respect to educational goods. Or perhaps the greater productivity of those who are advantaged with respect to educational goods can be channelled, via redistributive policies, to those who are less productive. To what extent educational goods enjoyed by some lead to benefits by others depends in large part on 
policy in other areas. Policy decisions affecting school segregation should be approached in an integrated or holistic fashion, in light of the interactions between education and other policy areas.

To summarize, the consequentialist approach evaluates admissions policies by considering the benefits or goods that they are claimed to produce, and how those benefits or goods are distributed. Segregation may make some - or all - schools better at producing some of those goods but worse at producing others, and there will also be trade-offs between the value of producing more goods, educational or otherwise, and the value of distributing them well and distributing access to them fairly.

\section{Non-Consequentialist}

Debates about admissions policies also involve nonconsequentialist considerations, which are often expressed in the language of rights. These can tell against acting in ways that promote good outcomes or can permit individuals to act in ways that fail to promote them. Identifying the correct trade-off between different educational goods, and what justice demands with respect to their distribution and access to them, might not settle the question of what policymakers ought to do.

Individuals or groups might have rights that protect them from certain kinds of treatment. Such rights limit how good outcomes can permissibly be produced. Many object to admissions policies that realise valuable composition effects by legally requiring particular children to attend particular schools. One way of elaborating this nonconsequentialist thought appeals to the means principle, according to which it can be morally wrong to use others to advance good outcomes. A child who is legally required to attend a particular school because her inclusion within it would be optimal in terms of producing educational goods and their fair distribution might object that such a policy treats her as a means for the benefit of others, rather than as an end in herself.

Some non-consequentialists insist that individuals or groups have the moral option to engage in activities that fail to produce the best outcome overall (Kagan, 1989). For example, it might be that groups of like-minded people have the right to set up - and choose to use - schools that select pupils on the basis of particular characteristics such as ability to pay, gender or religion. Some hold that they have that right even if allowing the proposed schools would produce worse outcomes than could be achieved by different admissions policies. The issue of individuals' rights to produce bad - or even unjust - distributive outcomes typically arises, in the school case, in discussion of parents' right to send their children to elite private schools (Swift, 2003).

Non-consequentialists tend to endorse free association. Individuals who share particular religious, aesthetic or sporting interests are morally permitted to cooperate to pursue their commitments and to exclude from the association those who do not share their goals. Furthermore, associative freedom should be protected by the community, provided that the group is not motivated by racist or other wrongful discriminatory attitudes. Standardly, what is protected is association between consenting adults. But schooling raises more difficult issues partly because it involves some (adults) deciding how others (children) are educated. Non-consequentialists disagree about the implications of their view for school policy because they hold different views about who are the bearers of the rights in question.

Parent-focused non-consequentialists hold that parents have a moral claim to choose the school their child attends. This right is defended by some as a part of parents' entitlement to pursue their own conception of the good (Fried, 1976; Galston, 2002). On this view, a religious or other group has the right to set up a school and to decide its admissions policies on the basis of the group's values. Once the mix of schools has been settled by different groups exercising their freedom of association, parents have the right to choose the school their children attend from the set of schools willing to admit them. A group might see educating children of its members as part of its mission and refuse to admit children of non-members; a group might want to teach only girls or boys, or less or more able children, or children of parents with a particular religious affiliation, and so on. To the extent that freedom of association is taken seriously, groups ought to enjoy freedom over their schools' admissions criteria, and parents ought to enjoy the right to apply to any school and for their applications to be judged according to the school's particular admissions code.

Child-focused non-consequentialists hold that the bearers of non-consequentialist rights in education are not parents but children. So parents' freedom to choose their children's school is limited. ${ }^{2}$ Various versions are available, depending on the particular rights ascribed to children. On one version, it is morally wrong for anyone parents as well as the political community - to force children to become a part of an association by sending them to schools that obstruct the development of their capacity for personal autonomy. On another, children's rights are violated whenever they are directed towards controversial belief systems. The particular worry here concerns adults intentionally enrolling their children into controversial conceptions of the good, such as particular religious doctrines. Non-consequentialist arguments for parental choice assume that parents have a moral right to determine (at least provisionally) the religious or occupational ends that their child pursues; but if everyone has a right to set her own ends, then parents do not enjoy that right over their children (Clayton, 2006). According to child-focused nonconsequentialism, then, it may not be fundamentally 
objectionable for a government to deny parents the opportunity to send their child to a school that selects on the basis of religion.

Non-consequentialist considerations complicate the moral picture with respect to school admissions and school choice. The core idea is that a policy might wrong people even if it is effective in producing schools with pupil compositions that lead to better outcomes with regard to the production and distribution of educational goods. How that idea plays out in detail, and how radical a revision of educational policy it calls for, turns on the answer to further questions, such as whether non-consequentialist rights protect primarily children or their parents, and how exactly the rights in question are understood.

\section{Conclusion}

I have said nothing about the circumstances in which some kinds or degrees of educational segregation might produce good or bad consequences. Nor have I put the case for or against any selection criteria that schools might use. The curious reader can find out my more substantive views, at least on some of these issues, by following up the relevant citations. But my aim here has been just to set out, as clearly as possible given the space available, the range of considerations relevant to thinking about educational segregation and those selection policies that affect it.

One final note by way of conclusion. I emphasised at the beginning that segregation happens along many dimensions and in many domains. I have focused on schools, which are obviously educational institutions: educating children is their explicit purpose. But it follows from my broad conceptualisation of "education" that actually all forms of segregation have educational significance. All affect the production and distribution of knowledge, skills, attitudes and dispositions. They make a difference in those ways not only to children but also to adults - and they make a difference both to those adults who have deliberately chosen to segregate and those whose segregation results from the choices of others. So it is not only children whose education depends on other people's choices.

\section{References}

Brighouse, H., Ladd, H. F., Loeb, S., \& Swift, A. (2018). Educational goods: Values, evidence and decision making. Chicago University Press. https://doi.org/10.7208/chicago/9780226514208.001.0001

Clayton, M. (2006). Justice and legitimacy in upbringing. Oxford University Press. https://doi.org/10.1093/0199268940.001.0001

Clayton, M. (2018). Education. In S. Olsaretti (Ed.), The Oxford handbook of distributive justice (pp. 438-459). Oxford University Press. https://doi.org/10.1093/oxfordhb/9780199645121.013.16

Clayton, M., Mason, A., Swift, A., \& Wareham, R. (2018). How to regulate faith schools. Impact. Philosophical Perspectives on Education Policy, 25, 1-49. https://doi.org/10.1111/2048-416X.2018.12005.x

Clayton, M., Mason, A., Swift, A., \& Wareham, R. (2021). The political morality of school composition: The case of religious selection. British Journal of Political Science, 51, 827-844. https://doi.org/10.1017/S0007123418000649

Fried, C. (1976). Right and wrong. Harvard University Press.

Galston, W. (2002). Liberal pluralism: The implications of value pluralism for political theory and practice. Cambridge University Press. https://doi.org/10.1017/CBO9780511613579

Kagan, S. (1989). The limits of morality. Oxford University Press.

Swift, A. (2003). How not to be a hypocrite: School choice for the morally perplexed parent. Routledge. https://doi.org/10.4324/9780203423059

\section{Recommended Citation}

Swift, A. (2021). Segregation from a normative perspective. On Education. Journal for Research and Debate, 4(11). https://doi.org/10.17899/on_ed.2021.11.1

About the Author

Adam Swift is professor of political theory at University College London. His most recent book is Political Philosophy: A Beginners' Guide for Students and Politicians ( $4^{\text {th }} \mathrm{ed}$, Polity 2019). 
${ }^{1}$ What follows is a simplified and reduced version of the analysis offered in Clayton et al. (2021). For its application to a particular context see Clayton et al. (2018).

${ }^{2}$ Child-focused non-consequentialists might endorse parents' being granted some legal rights with respect to their children's education on the ground that parents are best placed or best motivated to act in ways consonant with their children's fundamental moral rights. Even if one denied that parents had any moral rights with respect to their children's upbringing, and saw their role as entirely fiduciary, one might still support a system of devolved authority that gave parents legal rights within certain limits. 